\title{
Upaya Meningkatkan Kompetensi Guru SMK Negeri 4 Gowa dalam Melaksanakan Proses Pembelajaran di Kelas Melalui Program Supervisi
}

\author{
H. Kamaruddin \\ Kepala UPT SMK Negeri 4 Gowa, Kabupaten Gowa - Provinsi Sulawesi Selatan \\ Corresponding Author. Email: kamaruddinrate15@gmail.com
}

\begin{abstract}
This study aims to improve the competence of teachers of SMK Negeri 4 Gowa in carrying out the learning process in the classroom through a supervision program. This research method uses action research. The subjects of this study were teachers at SMK Negeri 4 Gowa. This research instrument uses observation and documentation. While the data analysis technique used descriptive analysis. The results of this study indicate that the competence of teachers at SMK Negeri 4 Gowa in implementing the learning process in the classroom through the supervision program has increased. With an intensive supervision and guidance program, it is proven to be able to improve the professionalism of teachers in classroom learning.
\end{abstract}

Abstrak: Penelitian ini bertujuan untuk meningkatkan kompetensi guru SMK Negeri 4 Gowa dalam melaksanakan proses pembelajaran di kelas melalui program supervisi. Metode penelitian ini menggunakan penelitian tindakan. Subyek penelitian ini adalah guru-guru di SMK Negeri 4 Gowa. Instrument penelitian ini menggunakan observasi dan dokumentasi. Sedangkan teknik analisis datanya menggunakan analisis deskriptif. Hasil penelitian ini menunjukkan bahwa kompetensi guru SMK Negeri 4 Gowa dalam melaksanakan proses pembelajaran di kelas melalui program supervisi telah meningkat. Dengan program supervisi dan bimbingan intensif terbukti dapat meningkatkan profesionalitas guru dalam pembelajaran di kelas.

\author{
Article History \\ Received: 22-05-2021 \\ Revised: 01-06-2021 \\ Accepted: 23-06-2021 \\ Published: 07-07-2021

\section{Key Words:} \\ Competence of Teachers, \\ Learning Process, \\ Supervision.
}

\section{Sejarah Artikel}

Diterima: 22-05-2021

Direvisi: 01-06-2021

Disetujui: 23-06-2021

Diterbitkan: 07-07-2021

\section{Kata Kunci:}

Kompetensi Guru, Pembelajaran, Supervisi.

How to Cite: Kamaruddin, H. (2021). Upaya Meningkatkan Kompetensi Guru SMK Negeri 4 Gowa dalam Melaksanakan Proses Pembelajaran di Kelas Melalui Program Supervisi. Jurnal Paedagogy, 8(3), 414-421. doi:https://doi.org/10.33394/jp.v8i3.3894

https://doi.org/10.33394/jp.v8i3.3894

This is an open-access article under the CC-BY-SA License.

\section{Pendahuluan}

Pendidikan sebagai salah satu program Nasional yang strategis dan realistis se nantiasa dikembangkan sesuai dengan tuntutan dan kemajuan ilmu pengetahuan dan teknologi. Terciptanya insan-insan pembangunan yang berkualitas, cerdas dan terampil serta terdidik merupakan salah satu indikasi kemajuan yang dicapai dalam pendidikan. Agar proses pendidikan dapat berjalan efektif dan efisien, guru dituntut memiliki kompetensi yang memadai, baik dari segi jenis maupun isinya (Wahyuni, 2021; Supatni, 2017; Suginam, 2019; Sudirati, 2017; Purnamaraya, 2019). Guru adalah pribadi penting (key person) di kelas, besar pengaruhnya terhadap prilaku dan belajar siswa yang memiliki kecenderungan meniru dan beridentifikasi. Hal-hal yang berpengaruh itu antara lain adalah otoritas akademis dan nonakademis, kesehatan mental, kesenangan, cita-cita dan sikap, suasana kelas yang diciptakan oleh guru dan tindakannya. Pengaruh ini terjadi pada perkembangan intelek dan peningkatan motivasi belajar karena terpengaruhnya berbagai kebutuhan siswa, kendatipun dalam berbagai hal dapat juga menjadi hambatan seperti perasaan cemas.

Berdasarkan hasil pengamatan pra penelitian dalam melaksanakan tugasnya sebagai kepala sekolah ditemukan pada diri guru bahwa pada masa-masa awal pengalaman mengajarnya sebagai seorang guru pemula diliputi berbagai tekanan mental. Tekanan tersebut 
secara khusus dapat diusut dari berbagai sumber penyebabnya, tetapi yang jelas bahwa problema ini merupakan dinamika psikologis yang sentiasa menyertai proses penyesuaian diri guru dengan dunia barunya, yaitu berada di kelas dalam melaksanakan tugasnya sebagai seorang guru yang baik dan bertanggung jawab.

Sebagai guru pemula dalam melaksanakan tugas mengajar selalu dihinggapi atau diselimuti perasaan khawatir gagal melaksanakan tugas mengajar. Hal ini disebabkan karena keterbatasan pengalaman cara mengajar yang baik, sehingga timbul pertanyaan-pertanyaan dalam dirinya, seperti: Apa yang saya lakukan di depan kelas? apakan buku pelajaran ini? Alat apa yang saya gunakan menyampaikan materi atau bahan ajar yang sudah siap diajarkan? Dan apa yang saya lakukan apabila bahan ajar telah diajarkan seluruhnya, sementara waktu mengajar masih ada tersisa. Sebagi guru pemula hal-hal inilah merupakan beban rutin yang dirasakannya dalam menghadapi tugas mengajar di kelas setiap saat.

Berdasarkan uraian latar belakang di atas dan pengalaman langsung pada waktu mengadakan supervisi akademik di kelas, maka dapat diidentifikasi masalah yang menjadi fokus perhatian dalam pelaksanaan penelitian ini, antara lain :

a) Guru belum mempersiapkan persiapan mengajar seperti : program semester dan tahunan, silabus, rencana persiapan pembelajaran (RPP), dan buku penilaian.

b) Pada waktu membuka pelajaran, guru tidak melakukan apersepsi seperti : memberitahukan pokok bahasan dan subpokok bahasan, serta tujuan atau indikator yang ingin dicapai.

c) Pada waktu menyajikan atau menyampaikan materi atau bahan ajar, guru kurang mampu menggunakan metode yang sesuai dengan bahan ajar, tidak menggunakan alat bantu atau alat peraga, kurang melibatkan siswa dalam interaksi belajar mengajar, dan tidak melakukan evaluasi proses.

d) Pada akhir pembelajaran, guru tidak membuat rangkuman atau refleksi, dan tidak menggunakan waktu pembelajaran dengan baik.

Untuk memecahkan masalah yang telah dikemukakan di atas, maka dilakukan penelitian tindakan sekolah sebagai salah satu upaya untuk meningkatkan kompetensi guru dalam pelaksanaan proses belajar mengajar di kelas. Dalam pelaksanaannya dilakukan secara bertahap melalui kegiatan-kegiatan yang dilakukan oleh guru di kelas dan diamati secara langsung oleh peneliti untuk melihat secara langsung kelemahan dan kelebihan kegiatan proses belajar mengajar yang dilakukan oleh guru dalam hal :

1) Menyiapkan persiapan pembelajaran, seperti :

a) Program tahunan dan program semesteran.

b) Penyusunan silabus dan RPP.

c) Menyiapkan buku penilaian dll.

2) Melaksanakan program pembelajaran melalui tiga kegiatan, yaitu :

a. Pendahuluan.

b. Kegiatan pokok atau inti, dan

c. Kegiatan penutup.

3) Melakukan refleksi bersama dengan mendiskusikan kelemahan dan kelebihan yang dilakukan guru subjek selama proses belajar mengajar berlangsung.

Adapun tujuan yang akan dicapai dalam pelaksanaan penelitian ini yaitu untuk meningkatkan kompetensi guru SMK Negeri 4 Gowa dalam melaksanakan proses pembelajaran di kelas melalui program supervisi. 


\section{Metode Penelitian}

Penelitian ini di laksanakan di SMK Negeri 4 Gowa dengan guru-guru sebagai sasaran (responden) sebanyak 8 orang dengan rincian, yaitu guru normatif 3 orang, guru adaptif 3 orang, dan guru produktif 2 orang. Jenis tindakan yang dilakukan adalah action research, yaitu peneliti tindakan deskriptif dengan supervisi langsung di kelas terhadap 8 orang guru yang di jadikan sebagai responden. Penelitian ini ditempuh melalui dua siklus dengan dua pertemuan pada setiap siklusnya. Dalam melaksanakan penelitian ini tiap siklus terdiri atas empat tahapan, yaitu: perencanaan, pelaksanaan, observasi, dan refleksi (Arikunto dkk, 2012). Tahapan dalam penelitian ini dalam bentuk diagram gambar adalah sebagai berikut :

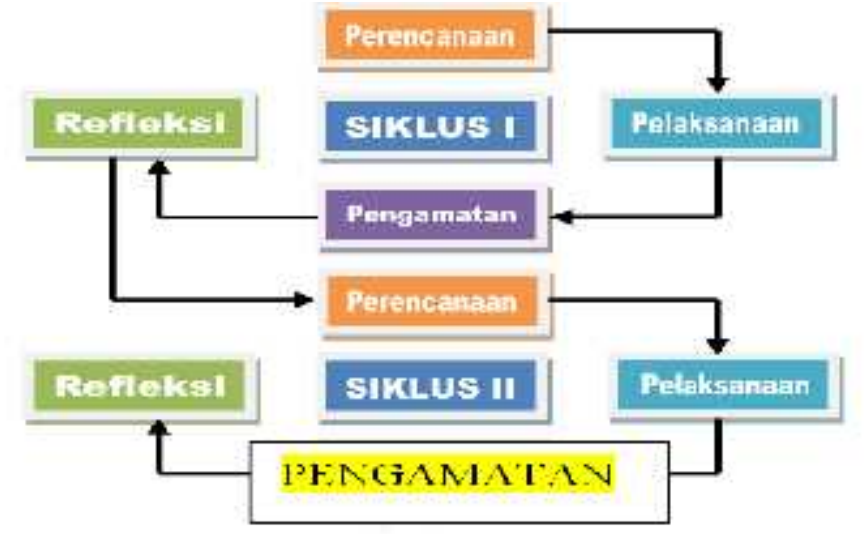

Gambar 1. Bagan Pelaksanaan PTK (Arikunto dkk, 2012)

Teknik pengumpulan data penelitian ini menggunakan lembar observasi dan dokumentasi. Teknik analisis data penelitian ini dilakukan secara kualitatif melalui tiga alur. Menurut Miles dan Hubermen (2014) alur yang meliputi reduksi data, penyajian data dan penarikan kesimpulan atau verifikasi.

\section{Hasil Penelitian dan Pembahasan}

Penelitian ini meliputi kegiatan-kegiatan penyusunan Rencana Program Pembelajaran (RPP) atau disain pembelajaran, pelaksanaan pembelajaran dengan mengaplikasikan disain pembelajaran, pemantauan di kelas, serta refleksi yang merupakan inti siklus yang dilaksanakan dalam dua siklus seperti yang telah disebutkan. Persiapan utama yang telah dilakukan sebelum kegiatan inti penelitian ialah pembahasan bersama fokus penelitian, pembuatan perangkat pembelajaran, pelaksanaan proses pembelajaran di kelas. Maka prosedur kerja yang ditempuh sebagai implementasi tindakan yang telah dilaksanakan :

\section{Deskripsi Siklus Pertama}

* Penyusunan perangkat pembelajaran yang akan dilaksanakan pada semester ganjil tahun ajaran 2018/2019.

* Pelaksanaan pembelajaran dalam suasana apa adanya oleh guru-guru dengan menggunakan perangkat pembelajaran yang telah dibuatnya. Bersamaan dengan kegiatan ini peneliti melakukan pemantauan dan penilaian berdasarkan format penilaian yang telah dipersiapkan.

* Setelah pembelajaran berlangsung, guru-guru merefleksikan kembali tentang pembelajaran yang telah dilaksanakan.

* Evaluasi tentang kelebihan dan kekurangan proses pembelajaran yang telah dilaksanakan oleh guru-guru di kelas. 
* Pemberian nilai kemampuan guru-guru dengan mempertimbangkan kemampuan yang dimiliki.

* Refleksi umum hasil kemampuan guru-guru yang telah melaksanakan proses pembelajaran yang telah dilakukan.

* Penyusunan program pembelajaran untuk pertemuan berikutnya sebagai tindakan kedua.

\section{Deskripsi Siklus Kedua}

Didalalam siklus kedua ini telah dilakukan hal-hal berikut:

* Penyusunan perangkat pembelajaran yang akan dilaksanakan pada semester ganjil tahun ajaran 2018/2019.

* Pelaksanaan pembelajaran dalam suasana apa adanya oleh guru-guru dengan menggunakan perangkat pembelajaran yang telah dibuatnya. Bersamaan dengan kegiatan ini peneliti mengadakan pemantauan dan penilaian berdasarkan format penilaian yang telah dipersiapkan.

* Setelah pembelajaran berlangsung, guru-guru merefleksikan kembali tentang pembelajaran yang telah dilaksanakan.

* Evaluasi tentang kelebihan dan kekurangan proses pembelajaran yang telah dilaksanakan oleh guru-guru di kelas.

* Pemberian nilai kemampuan guru-guru dengan mempertimbangkan kemampuan yang dimiliki.

* Refleksi umum hasil kemampuan guru-guru dalam melaksanakan proses pembelajaran yang telah dilakukan.

Dari uraian diatas maka dapat dilihat hasil dan refleksi berlangsung secara terpadu melalui proses: Perencanaan - pelaksanaan - pengamatan -dan refleksi. Keempat langkah tersebut merupakan satu kesatuan, baik dari tindakan ke tindakan dalam siklus yang sama, maupun dari siklus yang satu ke siklus yang kedua.

Tindakan daur ulang dilaksanakan sebagai upaya peningkatan kembali kemampuan guru-guru, penekanan pada hal-hal yang dianggap mendasar yang perlu mendapat perhatian dalam pembelajaran berikutnya. Sehingga guru-guru merasakan manfaat dari pemantauan dan penilaian yang telah dilakukan oleh peneliti.

\section{Pembahasan}

\section{Siklus Pertama}

Di dalam penelitian ini telah dikemukakan bahwa ada empat langkah dan penanggulangannya yang akan disajikan dalam bagian ini, yaitu: Perencanaan - pelaksanaan - pengamatan dan refleksi. Keempat langkah tersebut merupakan satu siklus atau putaran, artinya sesudah langkah keempat, lalu kembali lagi ketahapan berikutnya.

\section{Perencanaan}

Dalam langkah pertama ini, peneliti menyampaikan suatu rencana tentang program supervisi bagi guru-guru di kelas. Karena dengan program supervisi ini diharapkan dapat meningkatkan kemampuan mengajar dengan baik di kelas. Guru-guru menyatakan kesediannya dengan mengikuti jadwal pelajaran yang telah dibuat oleh sekolah pada semester ganjil tahun pelajaran 2018/2019, maka guru-guru mempersiapkan diri dengan menyiapkan perangkat pembelajaran dan bersedia untuk dipantau pada saat melakukan proses pembelajaran di kelas. Pada tahap ini pula disampaikan fokus penilaian yang perlu diketahui oleh guru-guru. Format penilaian atau instrumen supervisi yang akan menjadi sasaran pada saat guru-guru melakukan pembelajaran di depan kelas. 


\section{Pelaksanaan}

Setelah selesai perangkat pembelajaran, alat bantu, dan buku absensi dan buku penilaian. Guru-guru menyiapkan skenario pembelajaran yang siap disampaikan di depan kelas. Waktu yang digunakan dua jam pelajaran $(2 \mathrm{x} 45$ menit) untuk mata pelajaran normatif. Kegiatan awal, kemudian kegiatan pokok atau inti, Dan kegiatan akhir pembelajaran. Semuanya berjalan dengan baik sesuai dengan perencanaan semula.

\section{Pengamatan}

Dalam melaksanakan pengamatan ini peneliti dibantu oleh beberapa teman guru, termasuk sebagai Kepala SMK Negeri 4 Gowa, dengan nilai hasil supervisi sebagai berikut:

Tabel 1. Rekapitulasi Perolehan Nilai Hasil Supervisi Kelas Guru SMK Negeri 4 Gowa (Siklus I)

\begin{tabular}{|l|l|l|c|c|}
\hline No & Nama Guru (Responden) & Mata Pelajaran & Perolehan Nilai & Ket \\
\hline 1 & Dra. ST.Suttere & Bahasa Indonesia & 63 & C \\
\hline 2 & Rahmawati Syam, S.Pd & PPKn & 54 & D \\
\hline 3 & Muhammad Yunus, S.Ag & Pend.Agama Islam & 42 & D \\
\hline 4 & Ellyanti, S.Pd & Bahasa Inggris & 40 & D \\
\hline 5 & Dra. Hj.Rostiati Bachtiar & Matematika & 44 & D \\
\hline 6 & Suparman, ST & Fisika & 45 & D \\
\hline 7 & Dangan . S.Pd & Produktif TAV & 44 & D \\
\hline 8 & Abdullah, S.Pd & Produksi Grafika & 48 & D \\
\hline
\end{tabular}

Data di atas, terlihat bahwa masih ditemukan 7 guru sebagai responden dari 8 orang responden dalam penelitian ini yang perlu mendapat bimbingan karena mendapat perolehan nilai antara 40-54 yang berarti nilai ketergori D atau kurang. Guru tersebut sangat kurang dalam persiapan, seperti: penyusunan silabus, buku nilai. Pada kegiatan pendahuluan proses pembelajaran juga masih ditemukan kekurangan seperti: aprespsi dan motivasi, penyajian kurang sesuai dengan urutan materi, metode dan pendekatan, penggunaan alat peraga/alat bantu, bimbingan kepada siswa, teknik bertanya pengembangan keterampilan siswa dalam memecahkan masalah, menghubungkan materi pelajaran dengan budipekerti dalam kehidupan sehari-hari, edukasi proses, dan pencapaian tujuan pembelajaran. Demikian juga pada akhir pembelajaran masih ditemukam beberapa kekurangan, seperti: tidak melaksanakan refleksi, tidak membuat rangkuman, dan tidak ada pemberian tugas/PR. Dari perolehan nilai yang terkumpul hanya satu orang responden yang memperoleh nilai kategori $\mathrm{C}$ hal ini menandakan bahwa semua guru yang dijadikan responden pada SMK Negeri 4 Gowa masih memerlukan bimbingan dari pengawas dalam menyusun persiapan dan melaksanakan proses pembelajaran di Kelas.

\section{Refleksi}

Pada tahap ini penting untuk diketahui sejauh mana kemampuan guru-guru setelah melakukan pembelajaran di depan kelas. Pengungkapan kembali hal-hal yang dirasakan setelah berada di depan Kelas selama dua jam pembelajaran ( 2 x 45 Menit ), setelah itu peneliti, menyampaikan hal-hal yang masih dianggap perlu untuk diperhatikan dalam proses pembelajaran. Guru-guru merasa bisa memaklumi dimana kekurangan yang perlu diperbaiki pada proses pembelajaran yang nantinya menjadi bahan kajian pada proses pembelajaran berikutnya. Guru-guru menerima segala kekurangan seperti yang ada format penilaian yang dijadikan sebagai format supervisi kelas yang telah diperlihatkan dan dijadikan sebagai dasar pada siklus pertama dan perbaikan pada siklus berikutnya. 


\section{Siklus Kedua}

Setelah mengamati kemampuan guru-guru pada siklus petama diatas, maka peneliti perlu melanjutkan untuk siklus kedua untuk membandingkan dengan siklus pertama yang telah dilaksanakan dengan harapan ada tindak lanjut bimbingan yang telah dilaksanakan pada saat refleksi dengan guru-guru setelah dilaksanakan siklus pertama.

\section{Perencanaan}

Dalam langkah pertama ini, peneliti menyampaikan rencana tentang program supervisi bagi guru-guru di Kelas. Karena dengan program supervisi ini diharapkan dapat meningkatkan kemampuan mengajar di Kelas. Guru-guru menyatakan kesediaannya dengan mengikuti jadwal pelajaran yang telah dibuat oleh Sekolah. Pada semester ganjil tahun pelajaran 2018/2019, guru-guru mempersiapkan diri dengan menyiapkan perangkat pembelajaran dan siap untuk dipantau pada saat atau waktu yang telah ditentukan. Pada tahap ini disampaikan fokus penilaian yang perlu diketahui oleh guru-guru, format penilaian atau instrumen pengamatan yang akan menjadi sasaran pada guru-guru melakukan pembelajaran di depan kelas seperti pada siklus pertama.

\section{Pelaksanaan}

Setelah selesai pembuatan perangkat pembelajaran, alat bantu, dan administrasi siswa, guru-guru menyiapkan skenario pembelajaran yang siap disampaikan didepan kelas. Waktu yang digunakan dua jam pembelajaran untuk setiap mata pelajaran. Kegiatan pembelajaran pendahuluan, kemudian kegiatan pokok atau inti, dan mengakhiri pembelajaran dengan kegiatan penutup juga dapat berjalan dengan baik sesuai dengan perencanaan.

\section{Pengamatan}

Pengamatan yang telah dilaksanakan peneliti bersama dengan teman sejawat (Wakasek Kurikulum SMK Negeri 4 Gowa ) Pada siklus kedua ini, hasilnya dapat dilihat pada tabel dua, yaitu:

Tabel 2. REKAPITULASI PEROLEHAN NILAI HASIL SUPERVISI KELAS GURU SMK NEGERI 4 GOWA (SIKLUS 2)

\begin{tabular}{|l|l|l|c|c|}
\hline No & Nama Guru (Responden) & Mata Pelajaran & Perolehan Nilai & Ket \\
\hline 1 & Dra. ST.Suttere & Bahasa Indonesia & 86 & B \\
\hline 2 & Rahmawati Syam, S.Pd & PPKn & 77 & B \\
\hline 3 & Muhammad Yunus, S.Ag & Pend.Agama Islam & 78 & B \\
\hline 4 & Ellyanti, S.Pd & Bahasa Inggris & 79 & B \\
\hline 5 & Dra. Hj.Rostiati Bachtiar & Matematika & 80 & B \\
\hline 6 & Suparman, ST & Fisika & 75 & B \\
\hline 7 & Dangan. S.Pd & Produktif TAV & 81 & B \\
\hline 8 & Abdullah, S.Pd & Produksi Grafika & 80 & B \\
\hline
\end{tabular}

Dari hasil perolehan nilai guru-guru pada siklus kedua ini sudah menunjukkan kemampuan yang lebih dari siklus pertama, yaitu nilai nilai perolehan di atas 75-86 atau dengan kategori $\mathrm{B}$ atau baik. Ini berarti bahwa guru-guru menunjukkan suatu upaya peningkatan dalam hal kemampuan melaksanakan proses pembelajaran dengan baik.

Kekurangan yang nampak hanya pada bagi dalam kegiatan pokok atau inti, yaitu: Penggunaan metode atau pendekatan yang kurang tepat, Teknik bertanya siswa yang harus selalu dibiasakan, bimbingan kepada siswa yang masih membutuhkan, mengembangkan keterampilan siswa. Menghubungkan materi pelajaran dengan budi pekerti, dan penilaian proses serta pencapaian tujuan pembelajaran siswa harus dipertajam. Sedangkan pada bagian penutup, guru-guru sudah melakukannya dengan baik., Yaitu sudah membuat 
rangkuman/refleksi, memberi tugas/PR melaksanakan sesuai dengan waktu yang ada, dan mengakhiri pelajaran dengan baik.

\section{Refleksi}

Pada tahap ini penting untuk diketahui sejauh mana kemampuan guru-guru setelah melakukan pembelajaran di depan Kelas. Pengungkapan kembali hal-hal yang dirasakan setelah berada di depan Kelas selama dua jam pembelajaran ( 2x 45 Menit ). Setelah itu peneliti menyampaikan hal-hal yang masih dianggap perlu untuk diperhatikan dalam proses pembelajaran. Guru-guru merasa bisa memaklumi dimana kekurangan yang perlu diperbaiki pada proses pembelajaran yang nantinya menjadi bahan kajian pada proses pembelajaran berikutnya. Guru-guru menerima segala kekurangan seperti yang ada pada Format penilaian yang diperlihatkan dan dijadikan sebagai dasar pada siklus kedua ini yang sudah memperlihatkan nilai pemantauan yang memuaskan, yaitu sudah memperoleh nilai 75 keatas atau kategori baik. Hal ini diminta oleh peneliti agar apa yang dicapai pada siklus kedua ini agar terus ditingkatkan pada kegiatan proses pembelajaran pada masa-masa yang akan datang.

\section{Kesimpulan}

Kesimpulan yang diperoleh dari hasil penelitian ini antara lain, yaitu:

1) Upaya peningkatan kompetensi Guru dalam proses pembelajaran dapat dilakukan dengan cara melakukan supervisi secara rutin dan berkelanjutan di Kelas seperti yang dilakukan peneliti dengan dua siklus yang sudah menunjukkan adanya perbaikan dan peningkatan.

2) Keberhasilan siswa dalam pembelajaran ditentukan kompetensi guru dalam mempersiapkan diri dan mengelola kelas dengan baik.

3) Dengan program supervisi dan bimbingan kepada guru-guru muda dapat meningkatkan profesionalitas guru di masa-masa yang datang.

\section{Saran}

Adapun saran yang disampaikan berdasarkan hasil penelitian ini adalah; (1) Kepada pengawas sekolah, kepala sekolah agar mengefektifkan program supervisi kelas dalam upaya meningkatkan kemampuan guru dalam mengaktifkan proses pembelajaran di kelas. (2) Kepada peneliti selanjutnya, disarankan untuk mengembangkan atau melanjutkan penelitian yang sama di sekolah yang lain untuk meningkatkan kompetensi guru dalam proes pembelajaran. (3) Diharapkan kepada Dinas Pendidikan tetap memberikan kesempatan kepada guru muda untuk mengikutkan Diklat untuk pengembangan kompetensi dan lebih professional dalam menjalankan tugasnya sebagai guru muda.

\section{Daftar Pustaka}

Arikunto, S, Sukardjono, P Supardi. (2012). Penelitian Tindakan Kelas. Jakarta: Bumi Aksara.

Miles, M. B, Huberman, A.M. (2014). Qualitative Data Analysis, A Methods Sourcebook, Edition 3. USA: Sage Publications. Terjemahan Tjetjep Rohindi Rohidi, UI-Press.

Ekojuniarto. 2004. Pengembangan Silabus. Jakarta: Departemen Pendidikan Nasional. Dirjen pendidikan Dasar dan Menengah. Direktorat Tenaga kependidikan.

Departemen Pendidikan Nasional, 2005, Penelitian Tindakan Kelas Bahasa dan Sastra Indonesia. Materi Penelitian Terintegrasi, Jakarta: Departemen Pendidikan Nasional, Direktorat Tenaga Kpendidikan. 
Jamilan, J. (2017). Meningkatkan Kompetensi Guru Kelas dalam Proses Pembelajaran Melalui Supervisi Akademik di SD Negeri 4 Mataram. Jurnal Kependidikan: Jurnal Hasil Penelitian dan Kajian Kepustakaan di Bidang Pendidikan, Pengajaran dan Pembelajaran, 3(2). doi:https://doi.org/10.33394/jk.v3i2.675

Landa, Husen. Drs, 2003. Menyusun Dan Mengembangkan Instrumen Supervisi Pendidikan, Materi Pelatihan Kompetensi Pengawas, Jakarta: Departemen Pendidikan Nasional, Direktorat Pendidikan Lanjutan Pertama.

Purnamaraya, S. (2019). Upaya Meningkatkan Kompetensi Guru Kelas dalam Proses Pembelajaran Berdasarkan Kurikulum 2013 Melalui Supervisi Akademik di SD $\begin{array}{llll}\text { Negeri } & 45 \quad \text { Mataram. Jurnal Paedagogy, } & 6(2), & \text { 49-58. }\end{array}$ doi:https://doi.org/10.33394/jp.v6i2.2531

Puskur - Balitbang. (2006), Landasan Pengembangan Silabus dan Rencana Pelaksanaan Pembelajaran. Jakarta: Departemen Pendidikan Nasional.

Sabirin SJ. (2011). Meningkatkan Kemampuan Guru Dalam Melaksanakan Pembelajaran di Kelas Melalui Perencanaan Pembelajaran Standar Pada SMK Negeri 3 Takalar. PTS : Pengawas Dinas DIKPORA Kabupaten Takalar

Sabirin SJ. (2012). Pengaruh Kepemimpinan Kepala Sekolah Dan Motivasi Kerja Terhadap Kinerja Guru SMK Negeri 4 Takalar. PTS: Pengawas Dinas DIKPORA Kabupaten Takalar.

Sudiarti, D. (2017). Upaya Meningkatkan Kompetensi Guru Kelas dalam Proses Pembelajaran Melalui Supervisi Akademik di SDN 9 Cakranegara. Jurnal Kependidikan: Jurnal Hasil Penelitian dan Kajian Kepustakaan di Bidang Pendidikan, Pengajaran dan Pembelajaran, 3(1). doi:https://doi.org/10.33394/jk.v3i1.463

Suginam, A. (2019). Upaya Meningkatkan Kompetensi Guru Kelas dalam Proses Pembelajaran Melalui Supervisi Akademik di SD Negeri 4 Mataram. Jurnal Paedagogy, 6(2), 41-48. doi:https://doi.org/10.33394/jp.v6i2.2530

Supatni, P. (2017). Mengefektifkan Pelaksanaan Supervisi Akademik dalam Upaya Meningkatkan Kompetensi Guru Kelas dalam Proses Pembelajaran di SDN 36 Ampenan. Jurnal Kependidikan: Jurnal Hasil Penelitian dan Kajian Kepustakaan di Bidang Pendidikan, Pengajaran dan Pembelajaran, 3(1). doi:https://doi.org/10.33394/jk.v3i1.473

Wahyuni, T. (2021). Supervisi Klinis oleh Kepala Sekolah guna Meningkatkan Kompetensi Guru dalam Mengelola Administrasi Kelas di SD Negeri 42 Ampenan. Jurnal Paedagogy, 8(2), 264-270. doi:https://doi.org/10.33394/jp.v8i2.3561 